\title{
Diabetes associated with dominant insulin gene mutations: outcome of 24-month, sensor-augmented insulin pump treatment
}

\author{
Federica Ortolani $^{1} \cdot$ Elvira Piccinno $^{1} \cdot$ Valeria Grasso $^{2} \cdot$ Francesco Papadia $^{1}$ • \\ Rossana Panzeca $^{3}$ - Claudio Cortese ${ }^{2} \cdot$ Barbara Felappi $^{4} \cdot$ Albina Tummolo $^{1}$. \\ Marcella Vendemiale ${ }^{5} \cdot$ Fabrizio Barbetti $^{2,6}$
}

Received: 4 February 2015/ Accepted: 26 May 2015/Published online: 4 August 2015

(c) The Author(s) 2015. This article is published with open access at Springerlink.com

Insulin gene mutations, either dominant or recessive, can cause permanent neonatal diabetes mellitus (INS/PNDM), which is defined as diabetes with onset within 6 months of birth [1, 2]. More rarely, INS dominant mutations give rise to diabetes that presents during infancy [3]. In most patients with heterozygous, dominant INS mutations, C-peptide is in the normal-low range at diabetes outset, but over time declines to undetectable levels as a consequence of ongoing apoptosis of the pancreatic beta cells. This process is triggered by the sustained endoplasmic reticulum (ER) stress [2] induced by misfolding of mutant insulin trapped inside the beta cell. Thus, at least in principle, strategies aimed at relieving ER stress of beta cells may

Managed by Massimo Federici.

Elvira Piccinno

lorenzoeluigi@libero.it

Fabrizio Barbetti

mody.2@libero.it; fabrizio.barbetti@uniroma2.it

1 Department of Metabolic Diseases, Clinical Genetics and Diabetology, Giovanni XXIII Children's Hospital, Via Amendola 207, 70126 Bari, Italy

2 Department of Experimental Medicine and Surgery, University of Tor Vergata, Via Montpellier 1, 00133 Rome, Italy

3 Pediatrics Unit and Neonatal Intensive Care, Valduce Hospital, 22100 Como, Italy

4 Department of Pediatrics, University of Brescia, 25123 Brescia, Italy

5 Clinical Psychology, Giovanni XXIII Children's Hospital, 70126 Bari, Italy

6 Bambino Gesù Children's Hospital, IRCCS, 00164 Rome, Italy help to preserve endogenous insulin production from the normal allele.

During the last 8 years, we identified a total of 16 cases with dominant INS gene mutations from 13 different Italian centers [2-4]. Thirteen were diagnosed with INS/PNDM (or with diabetes with onset during infancy) (2-4 and FB unpublished observations) before year 2010 and were treated with standard insulin therapy. Currently, all of them show undetectable C-peptide values. Instead, the three patients diagnosed with a dominant INS mutation after year 2010 were started on continuous subcutaneous insulin infusion (CSII) within a week after diagnosis. The three patients carried the novel INS mutation c.149A $>$ G, p.Tyr50Cys (patient 1) and the already described c. $94 \mathrm{G}>\mathrm{A}$ p.Gly32Ser (patient 2) and c.314T $>$ C p.Leu105Pro (patient $3)$. Diabetes onset was at 1 month of age for patient 1 , 7 months for patient 2 , and 5 months and a half for patient 3.

In patient 1 , CSII was integrated with continuous (i.e., $24 \mathrm{~h}$ a day) glucose monitoring (CGM). CGM was set with alarms for hypoglycemia, with a 2-h automatic interruption of insulin delivery by the pump if glucose sensor detected a value $\leq 4.44 \mathrm{mmol} / \mathrm{l}(80 \mathrm{mg} / \mathrm{dl})$, and for hyperglycemia, with increased insulin infusion over basal level ("correction factor") of $0.025 \mathrm{U}$ for every $5.55 \mathrm{mmol} / \mathrm{l}(100 \mathrm{mg} / \mathrm{dl})$ above the glucose value of $8.33 \mathrm{mmol} / \mathrm{l}(150 \mathrm{mg} / \mathrm{dl})$, in order to obtain the narrowest plasma glucose fluctuations possible.

Patient 1 was discharged from the hospital after 1 month, patient 2 after 18 days, and patient 3 after 12 days. Informed consent was obtained from parents of patients. C-peptide was evaluated in patients 1 and 2 by two-site chemiluminescent immunometric assay. Assay employed for patient 1 (Liaison C-peptide, Diasorin, Saluggia, Italy) has a reported limit of detection of $0.01 \mathrm{ng} /$ 
$\mathrm{ml}(0.003 \mathrm{nmol} / \mathrm{l})$ and functional sensitivity of $0.03 \mathrm{ng} / \mathrm{ml}$ $(0.01 \mathrm{nmol} / \mathrm{l})$; for patient 2 , the assay (Immulite 2000 C-Peptide, Siemens) has a reported limit of detection and functional sensitivity of $0.08 \mathrm{ng} / \mathrm{ml}(0.03 \mathrm{nmol} / \mathrm{l})$. Blood samples for C-peptide determination were drawn after an overnight fast, without suspension of basal insulin infusion.

At follow-up as outpatients, no allergic reaction, lipoatrophy, or -hypertrophy at the site of catheter insertion were observed; in addition, no episodes of ketosis or severe hypoglycemia requiring new hospitalization were reported for any patient.

$\mathrm{HbA1c}$ is not a reliable method to evaluate metabolic control below the age of 6 months, because of the interfering effect of fetal hemoglobin: consequently, we do not report on patient 1's glycated hemoglobin during the first semester of CSII. HbA1c values determined in patients 1 and 2 six months after diabetes onset were nevertheless comparable: $50 \mathrm{mmol} / \mathrm{mol}(6.7 \%)$ for patient 1 (age 7 months) and $48 \mathrm{mmol} / \mathrm{mol}(6.5 \%)$ for patient 2 (age 13 months) (Table 1). At follow-up, HbA1c values 12, 18, and 24 months after diabetes onset were declining in patient 1 , while patient 2 showed a more irregular pattern (Table 1). Of note, insulin dose used for patient 2 was much lower for the entire period of CSII treatment (Table 1), suggesting that patient 2 may be more insulinsensitive than patient 1 . At strong variance with patients 1 and 2, patient 3 showed very high HbA1c from diabetes onset and never reached optimal metabolic control (Table 1).

Interestingly, C-peptide was measurable at diabetes onset $(1.04 \mathrm{ng} / \mathrm{ml}$ or $0.35 \mathrm{nmol} / \mathrm{l})$, but became undetectable in patient 2 (CSII only) after 12 and 24 months from diabetes diagnosis, consistent with other reports showing this pattern in patients with INS proteotoxic mutations [2, 3]. In contrast, after the initial decrement recorded the first month after diabetes presentation, C-peptide of patient 1 (integrated system CSII/CGM) increased with a current value at 24 months of age of $0.26 \mathrm{nmol} / \mathrm{l}$ (Fig. 1). However, it has

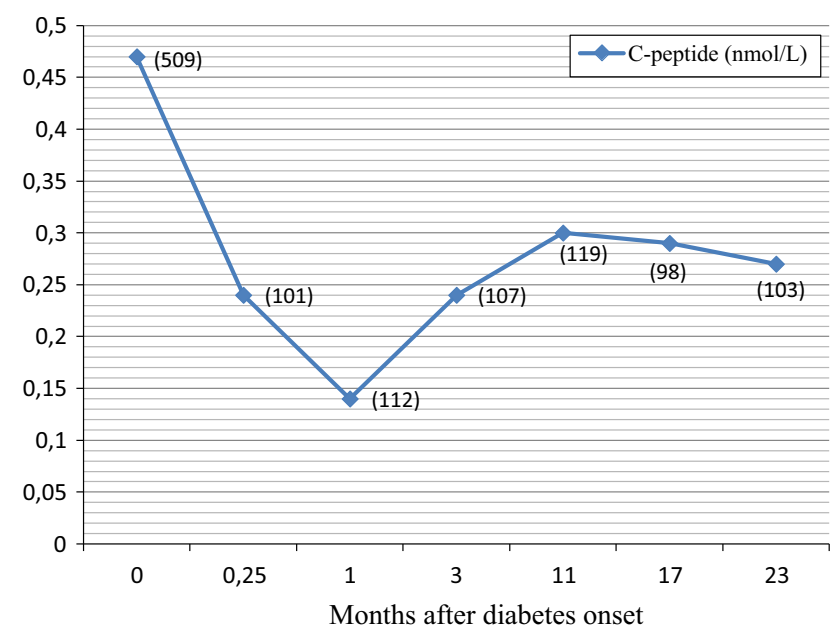

Fig. 1 C-peptide plasma level of patient 1 during the 24-month period of integrated CSII-CGM system. Numbers below each point are glucose values $(\mathrm{mg} / \mathrm{dl})$ at the time of blood drawing

to be noticed that because of different sensitivities between C-peptide assays utilized, a direct comparison of these two patients cannot be easily made. Nevertheless, this was a surprising finding that has no easy explanation. From the clinical standpoint, the effect of the p.Tyr50Cys mutation seemed more pronounced than p.Gly32Ser, because patient $1 \mathrm{had}$ an earlier diabetes presentation combined with a higher plasma glucose at onset $(509$ vs $293 \mathrm{mg} / \mathrm{dl}$ of patient 2). Interestingly, five patients previously described who bear INS/G23S mutation had diabetes onset at 6 months of age or beyond $[1,3]$. On the other side of the token, patient 1 had no HbAlc fluctuations (Table 1), and it is tempting to speculate that the reduction in patient's glycemic excursions obtained with CSII/CGM integrated system may have led to a substantial reduction in beta cell apoptosis consequent to the alleviation of endoplasmic reticulum crowding [5].

The results presented here indicate that CSII alone as well as sensor-augmented CSII is a feasible-and safe-

Table 1 Insulin dose and HbAlc in the three patients during 24-month period of treatment with CSII

\begin{tabular}{|c|c|c|c|c|c|c|c|c|c|c|c|c|}
\hline \multirow{2}{*}{$\begin{array}{l}\text { Time after } \\
\text { diabetes } \\
\text { onset }\end{array}$} & \multicolumn{4}{|c|}{ Patient 1} & \multicolumn{4}{|c|}{ Patient 2} & \multicolumn{4}{|c|}{ Patient 3} \\
\hline & $\begin{array}{l}\text { Total } \\
\text { insulin } \\
\text { (U/ } \\
\text { kg/day) }\end{array}$ & $\begin{array}{l}\text { Basal } \\
(\%)\end{array}$ & $\begin{array}{l}\text { Bolus } \\
(\%)\end{array}$ & $\begin{array}{l}\mathrm{HbA} 1 \mathrm{c} \\
{[\mathrm{mmol} / \mathrm{mol}} \\
(\%)]\end{array}$ & $\begin{array}{l}\text { Total } \\
\text { insulin } \\
\text { (U/ } \\
\text { kg/day) }\end{array}$ & $\begin{array}{l}\text { Basal } \\
(\%)\end{array}$ & $\begin{array}{l}\text { Bolus } \\
(\%)\end{array}$ & $\begin{array}{l}\mathrm{HbA} 1 \mathrm{c} \\
{[\mathrm{mmol} / \mathrm{mol}} \\
(\%)]\end{array}$ & $\begin{array}{l}\text { Total } \\
\text { insulin } \\
\text { (U/ } \\
\text { kg/day) }\end{array}$ & $\begin{array}{l}\text { Basal } \\
(\%)\end{array}$ & $\begin{array}{l}\text { Bolus } \\
(\%)\end{array}$ & $\begin{array}{l}\mathrm{HbA} 1 \mathrm{c} \\
{[\mathrm{mmol} / \mathrm{mol}} \\
(\%)]\end{array}$ \\
\hline At onset & 0.7 & 88 & 12 & n.r. & 0.15 & 100 & & $53(7)$ & 0.7 & 100 & 0 & $126.2(13.6)$ \\
\hline 6-7 months & 0.57 & 82 & 18 & $50(6.7)$ & 0.15 & 93.2 & 6.8 & $50(6.7)$ & 0.46 & 93 & 7 & $86(10)$ \\
\hline 12 months & 0.69 & 85 & 15 & $43(6.1)$ & 0.36 & 85 & 15 & $39(5.7)$ & 0.71 & 93 & 7 & $69(8.5)$ \\
\hline 18 months & 0.67 & 89 & 11 & $44(6.2)$ & 0.36 & 87 & 13 & $38(5.6)$ & 0.64 & 93 & 7 & $69(8.5)$ \\
\hline 24 months & 0.7 & 87 & 13 & $39(5.7)$ & 0.18 & 87 & 13 & $54(7.1)$ & & & & \\
\hline
\end{tabular}

n.r. not reported (HbA1c determined, but value not included in the table) 
therapeutic strategy for neonates or infants with diabetes, not only in the hospital setting, but at home. Moreover, CSII-CGM integrated system may be superior to CSII only, though we acknowledge that more cases must be studied to draw any robust conclusion. This may be probably obtained only through an international collaborative study, taking into consideration that PNDM is a rare condition $(1: 200,000$ live births in countries with low rate of consanguineous marriages) [4].

Acknowledgments The inspirational mentorship of Professor Francesco Dammacco is gratefully acknowledged. We thank the members of Early Onset Diabetes Study group of the Italian Society of Pediatric Endocrinology and Diabetes (ISPED) Dario Iafusco, Ivana Rabbone, and Riccardo Bonfanti for helpful discussion.

Conflict of interest The authors declare that they have no conflict of interest.

Ethical standard The study was approved by ethics review committees of each participating center.

Human and animal rights All procedures followed were in accordance with the ethical standards of the responsible committee on human experimentation (institutional and national) and with the Helsinki Declaration of 1975, as revised in 2008.

Informed consent Informed consent was obtained from all patients for being included in the study.
Open Access This article is distributed under the terms of the Creative Commons Attribution 4.0 International License (http://crea tivecommons.org/licenses/by/4.0/), which permits unrestricted use, distribution, and reproduction in any medium, provided you give appropriate credit to the original author(s) and the source, provide a link to the Creative Commons license, and indicate if changes were made.

\section{References}

1. Støy J, Edghill EL, Flanagan SE et al (2007) Insulin gene mutations as a cause of permanent neonatal diabetes. Proc Natl Acad Sci USA 104:15040-15044

2. Colombo C, Porzio O, Liu M et al (2008) Seven mutations in the human insulin gene linked to permanent neonatal/infancy-onset diabetes mellitus. J Clin Invest 118:2148-2156. doi:10.1172/ JCI33777

3. Bonfanti R, Colombo C, Nocerino V et al (2009) Insulin gene mutations as cause of diabetes in children negative for five type 1 diabetes autoantibodies. Diabetes Care 32:123-125. doi:10.2337/ $\mathrm{dc} 08-0783$

4. Iafusco D, Massa O, Pasquino B et al (2012) Minimal incidence of neonatal/infancy onset diabetes in Italy is 1:90,000 live births. Acta Diabetol 49:405-408. doi:10.1007/s00592-011-0331-8

5. Absood A, Gandomani B, Zaki A et al (2013) Insulin therapy for pre-hyperglycemic beta-cell endoplasmic reticulum crowding. PLoS One 8:e54351. doi:10.1371/journal.pone.0054351 